\title{
Role of Interleukin-17A in the Eosinophil Accumulation and Mucosal Remodeling in Chronic Rhinosinusitis with Nasal Polyps Associated with Asthma
}

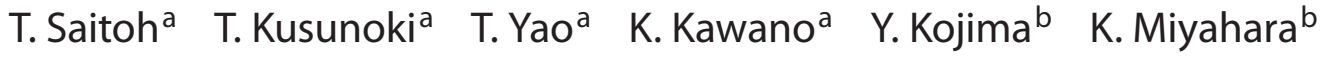 \\ J. Onoda ${ }^{a}$ H. Yokoi ${ }^{a} \quad$ K. Ikeda ${ }^{a}$ \\ aDepartment of Otorhinolaryngology, Juntendo University School of Medicine, and \\ ${ }^{b}$ Division of Biomedical Imaging Research, Juntendo University Graduate School of Medicine, Tokyo, Japan
}

\section{Key Words}

Nasal polyps $\cdot$ Chronic rhinosinusitis $\cdot$ Asthma $\cdot$

Interleukin-17A

\begin{abstract}
Background: Interleukin (IL)-17A is a highly inflammatory cytokine with a robust effect on stromal cells in many tissues. Although IL-17A is known to be associated with inflammatory lung disorders by triggering an accumulation of neutrophils, the effect of IL-17A on the upper airway is still uncertain. The expression of IL-17A and its role were investigated in the nasal polyps of chronic rhinosinusitis associated with asthma. Methods: IL-17A was detected by immunohistochemistry and quantitative real-time RT-PCR. The cellular source of IL-17A was examined by double staining with EG2, CD4 and neutrophil elastase. The tissue remodeling of the nasal polyps was evaluated by assessing the epithelial damage and basement membrane thickness. Results: Both the immunoreactivity and mRNA of IL-17A were significantly detected in the nasal polyps in comparison with control normal sinus mucosa. The localization of IL-17A expression predominantly coincided with eosinophils and CD4-positive lymphocytes. Furthermore, the number of IL-17A-positive cells correlated with tissue eosinophils, but not with neutrophils. The degree of epithelial damage and basement membrane
\end{abstract}

thickness was dependent on the number of infiltrated IL17A-positive cells. Conclusion: The present study suggests, for the first time, that IL-17A plays an important role in the eosinophil accumulation in the nasal polyps and the remodeling of the nasal polyps of chronic rhinosinusitis associated with asthma.

Copyright $\odot 2009$ S. Karger AG, Basel

\section{Introduction}

Chronic rhinosinusitis (CRS) is defined as persistent inflammation of the nasal and paranasal cavity mucosa lasting $\geq 3$ months [1]. Based on an epidemiological study in the United States, approximately $16 \%$ of the population has CRS. The prevalence and medical costs of CRS are increasing and, therefore, have become important social issues [2].

Although CRS is a multifactorial disease and a heterogeneous group of disease, with different underlying etiologies and pathophysiologies, many published studies proposed to differentiate CRS without nasal polyps and CRS with nasal polyposis [3-6]. Patients with CRS without nasal polyps appear more likely to manifest signs of bacterial infection and have been reported to have a better response to medical treatment [7]. The phenotype of

\section{KARGER}

Fax +41613061234 E-Mail karger@karger.ch www.karger.com

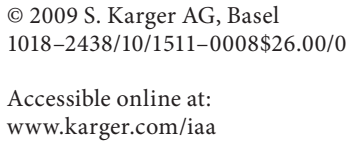


CRS without nasal polyps can be characterized by neutrophil recruitment into sinus effusion due to both the upregulation of adhesion molecules of the vascular endothelium induced by IL-1 and the enhanced secretion of chemoattractants of neutrophils, IL-8 from epithelial cells and neutrophils [8-11].

The histomorphological patterns of CRS with nasal polyps are characterized by the predominance of eosinophils and mixed mononuclear cells and the relative paucity of neutrophils [12]. Mucosal infiltration with enriched eosinophils in CRS with nasal polyps may be the distinctive feature of tissue eosinophilia, which is more refractory to surgical cure and is frequently associated with bronchial asthma $[13,14]$. Several studies have reported the aspects of the clinical relationship between CRS and asthma [15-17]. The Th2-driven immune response in the sinonasal mucosa of CRS is similar to lung tissue of asthma $[18,19]$. The histopathological features of asthma, namely, the tissue eosinophils, epithelial damage and basement membrane (BM) thickening of the lower airway [20,21], have been reported to be present in sinonasal specimens with CRS [22].

A Th2-dominant chronic inflammation of the lower airway with eosinophils is widely accepted as a fundamental characteristic of asthma. However, there is increasing recognition of non-Th2-type non-eosinophilic forms of asthma, particularly in subjects with severe disease. Several investigators [23-26] found asthmatic patients to have neutrophil- rather than eosinophil-rich pulmonary inflammation. Non-eosinophilic asthmatics who are steroid resistant and have refractory symptoms also tend to show non-Th2 cytokine- and neutrophildominant inflammation.

Accumulating evidence suggests an important role for IL-17A in the pathogenesis of non-Th2-type asthma. Sputum and blood samples from asthmatics have been shown to contain elevated levels of IL-17A [27-30]. IL-17A enhances IL- 6 , IL- 8 and GRO- $\alpha$ secretion by human bronchial fibroblasts [27] and IL- 6 and IL- 8 from human airway smooth muscle cells $[31,32]$. IL- 8 and GRO- $\alpha$ are known to be chemoattractants for neutrophils and IL-6 is a neutrophil-activating cytokine. Although IL-17A is hypothesized to contribute to the underlying pathogenesis of intractable CRS with nasal polyps similar to asth$\mathrm{ma}$, a few but fragmental reports regarding the expression of IL-17A in CRS have been presented. The exact function of IL-17A still remains unknown [33-35].

These experiments were designed to investigate the expression and localization of the protein and mRNA expression of IL-17A in sinonasal polyps associated with asthma. Furthermore, IL-17A immunoreactivity was compared with the tissue infiltration of eosinophils and neutrophils, the epithelial damage, BM thickness and the clinical profiles.

\section{Material and Methods}

\section{Patients}

The present study totally included 51 patients. The control group included 6 patients (4 females, aged 47-72 years, mean age 60 years, and 2 males, aged $48-61$ years, mean age 55 years). The CRS with asthma group included 45 patients (20 females, aged 2961 years, mean age 49 years, and 25 males, aged $28-78$ years, mean age 51 years). CRS with nasal polyps was diagnosed based on the criteria of the EAACI position paper [36], i.e. having 2 or more symptoms including blockage/congestion, discharge, anterior/ posterior drip, facial pain/pressure and reduction or loss of smell for at least 3 months and any endoscopic signs including polyps, mucopurulent discharge from the middle meatus, or edema/mucosal obstruction primarily in the middle meatus and/or mucosal changes within the ostiomeatal complex and/or sinuses. None of the patients were treated with systemic or topical corticosteroids, or other immune-modulating drugs at least 1 month before surgery, although some patients received topical corticosteroids, antihistaminic agents and/or macrolides. Patients with CRS with nasal polyps associated with current signs of purulent nasal discharge, chronic obstructive pulmonary disease, diffuse panbronchiolitis, or fungal sinus disease, congenital mucociliary diseases, or cystic fibrosis were excluded from this study. The presence of nasal discharge, postnasal drainage, nasal obstruction, headache and anosmia were recorded and their severity was defined as follows: severe $=3$, moderate $=2$, slight $=1$ and absence $=0$, based on a previous paper [37]. The disease extent on computed tomographic scans was categorized according to Lund and Mackay [38]. All patients gave their written informed consent and the study was approved by the Ethics Committee of Juntendo University School of Medicine.

The diagnosis of asthma was based on the definition of the American Thoracic Society. The total serum immunoglobulin E (IgE) and specific serum IgE against common inhalant allergens were also determined. The atopic status was defined as having more than 500 units of total serum IgE. All patients were treated with bronchodilators, including theophylline, $\beta$-adrenergics and inhaled corticosteroids, in the same manner.

\section{Sampling of Tissue Specimens}

Surgically removed human nasal polyps located in the middle meatus were obtained from the patients with CRS. Control samples were obtained from removed normal mucosal membranes of the sphenoid sinus at operation of pituitary adenoma. The samples were fixed in $10 \%$ formalin, embedded in paraffin wax, processed routinely and stained with hematoxylin-eosin. The samples for real-time RT-PCR were snap-frozen in liquid nitrogen and stored at $-80^{\circ} \mathrm{C}$.

Antibodies and Reagents

Rabbit anti-human IL-17A antibody was purchased from Santa Cruz (Santa Cruz Biotechnology, Santa Cruz, Calif., USA). Mouse anti-human neutrophil elastase obtained from Dako (Co- 
penhagen, Denmark). Mouse anti-human EG2 antibody was purchased from Pharmacia (Uppsala, Sweden). Mouse anti-human CD4, 1F6 was obtained from Abcam (Tokyo, Japan).

\section{Immunohistochemistry}

The nasal polyps were fixed in $10 \%$ formalin, embedded in paraffin wax, processed routinely and then prepared as routine semi-thin sections $(3.5 \mu \mathrm{m})$. The primary antibodies were IL-17A 1:80, EG2 1:100 and neutrophil elastase 1:100. The sections were stained by the Ventana iVEWTM DAB Detection kit using a Ventana automated stainer (Ventana Japan K.K., Yokohama, Japan). The sections treated with control mouse and rabbit IgG1 served as negative controls.

\section{Double Immunofluorescent Staining}

For immunostaining, the samples were pretreated for $30 \mathrm{~min}$ with phosphate-buffered saline containing $1 \%$ (wt/vol) goat serum (Sigma-Aldrich, Poole, UK). Primary antisera were applied at the following concentrations: rabbit anti-IL-17A 1:100, mouse anti-EG2 1:100, mouse anti-CD4 1:50 and mouse anti-neutrophil elastase 1:100. For IL-17A/EG2, IL-17A/CD4 and IL-17A/neutrophil elastase dual labeling, the IL-17A primary antibody was applied for $24 \mathrm{~h}$ at $4^{\circ} \mathrm{C}$, incubated with the appropriate secondary antibody and rinsed 3 times with phosphate-buffered saline before each of the primary antibodies (EG2, CD4, neutrophil elastase) were applied for $1 \mathrm{~h}$ at room temperature. The slides were rinsed 3 times with phosphate-buffered saline before incubating for $2 \mathrm{~h}$ with appropriate secondary antisera: Alexa-Fluor 488-conjugated goat anti-rabbit (Sigma-Aldrich) 1:300 and Alexa-Fluor 594-conjugated goat anti-mouse 1:300 (Sigma-Aldrich). After rinsing with phosphate-buffered saline, the samples were mounted using Vectashield Mounting Medium (Vector Laboratories, Inc., Burlingame, Calif., USA). Subsequently, the slides were observed on a fluorescence microscope (Zeiss, Hallberg, Germany).

\section{Quantitative Real-Time RT-PCR}

Total RNA was extracted from clinical tissue samples (30 mg) using the Aurum Total RNA kit (BioRad Laboratories, Hercules, Calif., USA). RNA quality was assessed with the Experion ${ }^{\mathrm{TM}}$ System (BioRad Laboratories) using the Experion ${ }^{\mathrm{TM}}$ RNA StdSens Analysis Kit (BioRad Laboratories) for representative results. cDNA was synthesized from $800 \mathrm{ng}$ RNA with the high-capacity cDNA RT kit (Applied Biosystems Inc., Foster City, Calif., USA). Real-time RT-PCR was performed for IL-17A using the 7500 Fast Real Time PCR System (Applied Biosystems Inc.) and TaqMan gene Expression Assays (assay identification number Hs00936345_m1), according to the manufacturer's specifications. The data analysis was done by standard curve method using the 7500 software version 2.0.1 (Applied Biosystems Inc.). All results were normalized to $\beta$-actin to compensate for differences in the amount of cDNA (assay identification number Hs99999903 $\mathrm{m} 1)$.

\section{Analysis of Infiltrated IL-17A-Positive Cells, Eosinophils and} Neutrophils

To evaluate the degree of the infiltration of IL-17A-positive cells, eosinophils and neutrophils, 2 of the authors independently counted the number of eosinophils in 5 fields with cell clusters using light microscopy ( $400 \times$ magnification).
Table 1. Comparison of histological findings between controls and CRS

\begin{tabular}{lrll}
\hline & $\begin{array}{l}\text { Control subjects } \\
(\mathrm{n}=6)\end{array}$ & $\begin{array}{l}\text { CRS with asthma } \\
(\mathrm{n}=45)\end{array}$ & p value \\
\hline IL-17A-positive cells & $0.5 \pm 1.3$ & $18.8 \pm 23.6$ & $<0.001$ \\
Eosinophils & $2.6 \pm 6.1$ & $75.3 \pm 96.7$ & $<0.001$ \\
Neutrophils & $2.1 \pm 1.2$ & $15.0 \pm 24.9$ & $<0.001$ \\
Epithelial damage, \% & $15.4 \pm 2.6$ & $56.1 \pm 22.7$ & $<0.001$ \\
BM thickness, $\mu \mathrm{m}$ & $1.6 \pm 1.8$ & $10.8 \pm 10.0$ & $<0.001$ \\
\hline
\end{tabular}

\section{Analysis of the Epithelial Damage and BM Thickness}

Observations of epithelial damage and BM thickness were performed on sections stained with hematoxylin-eosin by 2 of the authors independently. The image was acquired with a CCD camera connected to a personal computer. The length of the epithelia and BM thickness were measured using the KS400 Image Analysis System (KS400, Zeiss, Göttingen, Germany).

The staging of epithelial damage was revealed as the quantification of epithelial loss, namely, the length of epithelial sloughing was expressed as a percentage of the total epithelial length [39]. The epithelial damage of the control group included the physiological sloughing and artifacts. In fact, it is difficult to completely omit artifacts. Therefore, epithelial damage was observed under the same conditions in both nasal polyps and the control group. Surgeons with the same skill carefully removed the samples. The samples were fixed in formalin and stained with hematoxylin-eosin using the same procedures described above. The BM thickness was selected in the 5th field from the top $(400 \times$ magnification) located in severely thickened regions and calculated as the mean after inspection of the entire specimen. The BM thickness included the subepithelial fibrosis beneath the BM [40].

\section{Statistical Analyses}

The data were expressed as the mean \pm SD. Statistical analyses were evaluated using Pearson's correlation coefficient and Student's $t$ test in StatMate III for Windows. Differences were considered to be significant if $\mathrm{p}<0.05$.

\section{Results}

\section{Group of Control Subjects}

Little proliferation of epithelial or goblet cells was observed in the epithelial layers of the control group, whereas there were only nominal findings of epithelial sloughing. The subepithelial layers showed only a few inflammatory cells and fibroblasts (fig. 1a). The average numbers of IL-17A-positive cells, eosinophils and neutrophils in the subepithelial layers are described in table 1. 
Fig. 1. Histopathological sections from normal sinus mucosa and nasal polyp sections by hematoxylin-eosin staining. a Normal sinus mucosa of the control group shows little or no epithelial sloughing, eosinophils and BM thickening. b Nasal polyp sections from the CRS group show aggressive infiltrating eosinophils (arrows), severe epithelial sloughing (asterisks) and BM thickness (double arrows).
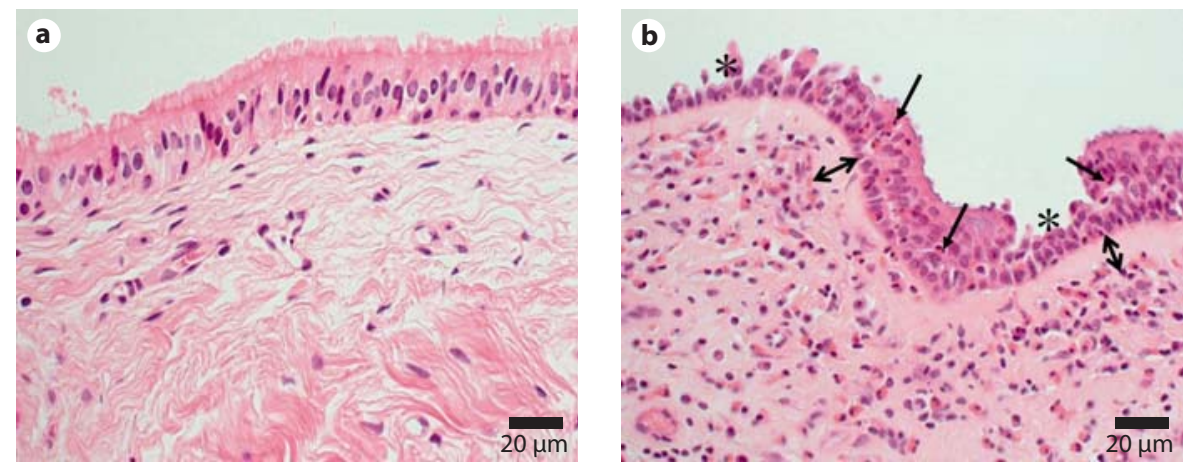
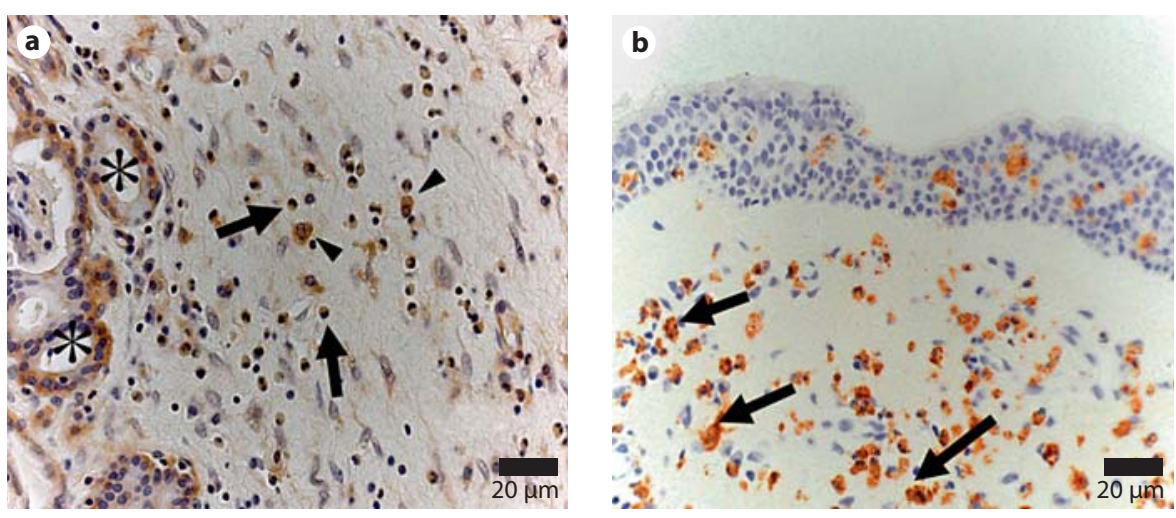

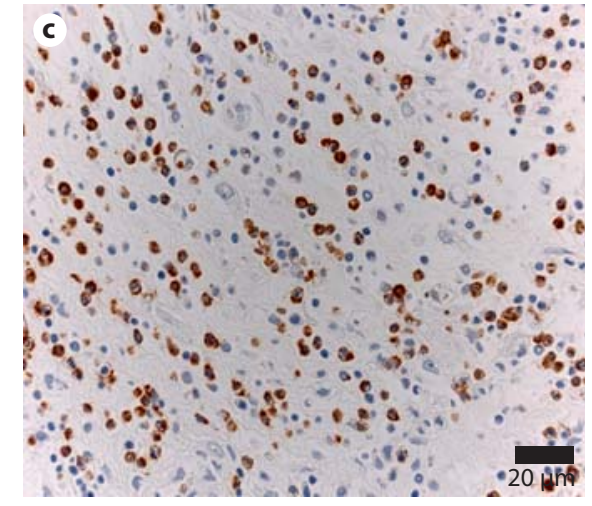

Fig. 2. Photographs of immunohistochemistry of IL-17A (a), EG2 (b) and neutrophil elastase (c). a Distribution and localization of IL-17A-positive cells are eosinophils (arrows), plasma cells (arrow heads) and acinus of the serous gland (asterisks). b Most of the

\section{Group of CRS with Asthma}

Patients of CRS associated with asthma showed computed tomographic scores $(16.2 \pm 5.4)$ and total symptomatic scores $(8.1 \pm 2.5)$. In the CRS with asthma group, the subepithelial layers showed numerous inflammatory cells with proliferating fibroblasts, and the epithelial layers contained both proliferating epithelial and goblet cells (fig. 1b). The number of IL-17A-positive cells (fig. 2a) was significantly increased in comparison with that of controls $(\mathrm{p}<0.001$; table 1$)$. Among the eosinophils identified by hematoxylin-eosin staining, $90.7 \pm 5.0 \%(n=5)$ were the EG2-positive activated type (fig. 2b). There were significantly more eosinophils in the CRS with asthma group than in the control group ( $\mathrm{p}<0.001$; table 1$)$. There were significantly more neutrophils in the subepithelial layers in the CRS group (fig. 2c) than in the control group ( $p<0.001$; table 1). The average epithelial damage and $\mathrm{BM}$ thickness in the CRS with asthma group were sig-
EG2-positive cells of the nasal polyps are eosinophils. Some of the EG2-positive cells are self-melted and engulfed by macrophages (arrows). c Moderate infiltration of neutrophils in nasal polyps is seen.

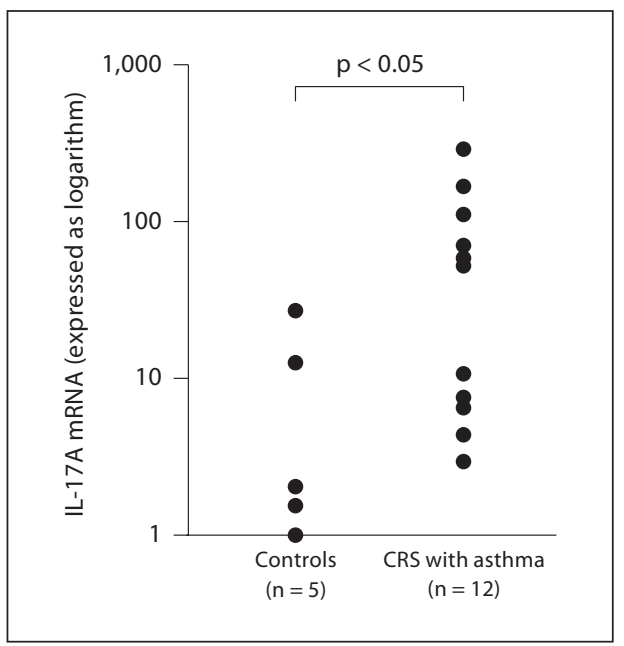

Fig. 3. Measurement of IL-17A mRNA by real-time RT-PCR. The relative levels of expression significantly increased in the nasal polyps in comparison with the controls. 

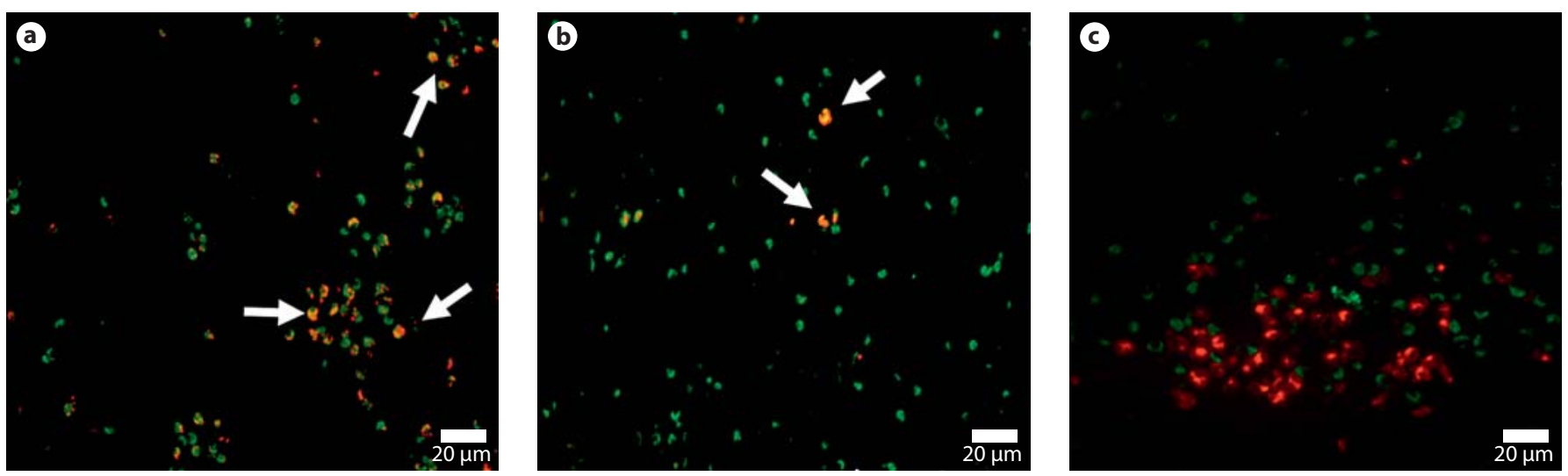

Fig. 4. Double immunofluorescent staining with IL-17A (green)/EG2 (red) (a), IL-17A (green)/CD4 (red) (b) and IL-17A (green)/neutrophil elastase (red) (c). Note the inflammatory cells showing double staining (arrows).

nificantly greater than those in the control group (epithelial damage, $\mathrm{p}<0.001$; BM thickness, $\mathrm{p}<0.001$; table 1 ). In addition to immunoreactivity, quantitative real-time RT-PCR showed a significant upregulation of IL-17A mRNA (fig. 3).

\section{Relevance of IL-17A-Positive Cells to Other}

Inflammatory Cells, Epithelial Damage and BM

Thickness

The cellular sources of IL-17A were examined with double immunofluorescence (fig. 4). IL-17A-positive cells were $64.3 \pm 7.7 \%(n=5)$ of the EG2-positive cells, whereas $27.1 \pm 5.8 \%(\mathrm{n}=10)$ of the CD4-positive cells were stained with IL-17A. Moreover, the number of CD4-positive cells stained with IL-17A had a significant correlation with the number of eosinophils ( $\mathrm{n}=10, \mathrm{r}=0.64, \mathrm{p}<$ 0.05). Most of the neutrophils were negative for IL-17A immunoreactivity $(4.8 \pm 3.4 \%, \mathrm{n}=5)$. The infiltration of IL-17A-positive cells had a significant correlation with the number of eosinophils $(\mathrm{n}=45, \mathrm{r}=0.46, \mathrm{p}<0.01$; fig. 5a), but not with neutrophils. The infiltration of IL17A-positive cells had a significant correlation with the epithelial damage $(\mathrm{n}=45, \mathrm{r}=0.37, \mathrm{p}<0.05$; fig. $5 \mathrm{~b})$ and BM thickness ( $\mathrm{n}=45, \mathrm{r}=0.54, \mathrm{p}<0.001$; fig. $5 \mathrm{c})$.

\section{Relationship of Epithelial Damage and BM Thickness} with Eosinophilic Infiltration

The eosinophilic infiltration inside the subepithelial layer also had a significant correlation with the epithelial damage ( $\mathrm{n}=45, \mathrm{r}=0.53, \mathrm{p}<0.001$; fig. $6 \mathrm{a})$ and BM thickness ( $\mathrm{n}=45, \mathrm{r}=0.51, \mathrm{p}<0.001$; fig. $6 \mathrm{~b})$.

\section{Relevance of Clinical Data to Histological Data}

$\mathrm{CT}$ and symptom scores and the number of IL-17Apositive cells did not show a correlation. There is no difference in the number of IL-17A-positive cells between atopic $(n=10)$ and nonatopic asthmatics $(n=32)$.

\section{Discussion}

The present study regarding IL-17A expressed in nasal polyps of CRS can be summarized as follows: (1) IL-17A immunoreactivity was detected in the inflammatory cells in the nasal polyps; (2) IL-17A mRNA was significantly enhanced in the nasal polyps in comparison with the controls; (3) the localization of IL-17A expression predominantly coincided with eosinophils and CD4-positive lymphocytes; (4) IL-17A correlated with eosinophils, but not with neutrophils, in the subepithelial layers, and (5) the degree of epithelial damage and BM thickness were dependent on the number of infiltrated IL-17A-positive cells.

IL-17A mRNA and/or proteins were reported to have increased in the lungs, sputum, bronchoalveolar lavage fluids or sera from asthmatics [27-30]. Since immunological aspects of the sinonasal tissue of CRS are known to be similar to those of the lung tissues of asthma [18, 19], IL-17A expression was assessed in CRS. Molet et al. [35] reported that IL-17A immunoreactivity was greatly increased in nasal polyps in comparison with control nasal turbinate. On the other hand, no significant differences were found at the mRNA level of IL-17A among CRS with nasal polyps, CRS without nasal polyps and the controls [41]. The present study demonstrated the signif- 

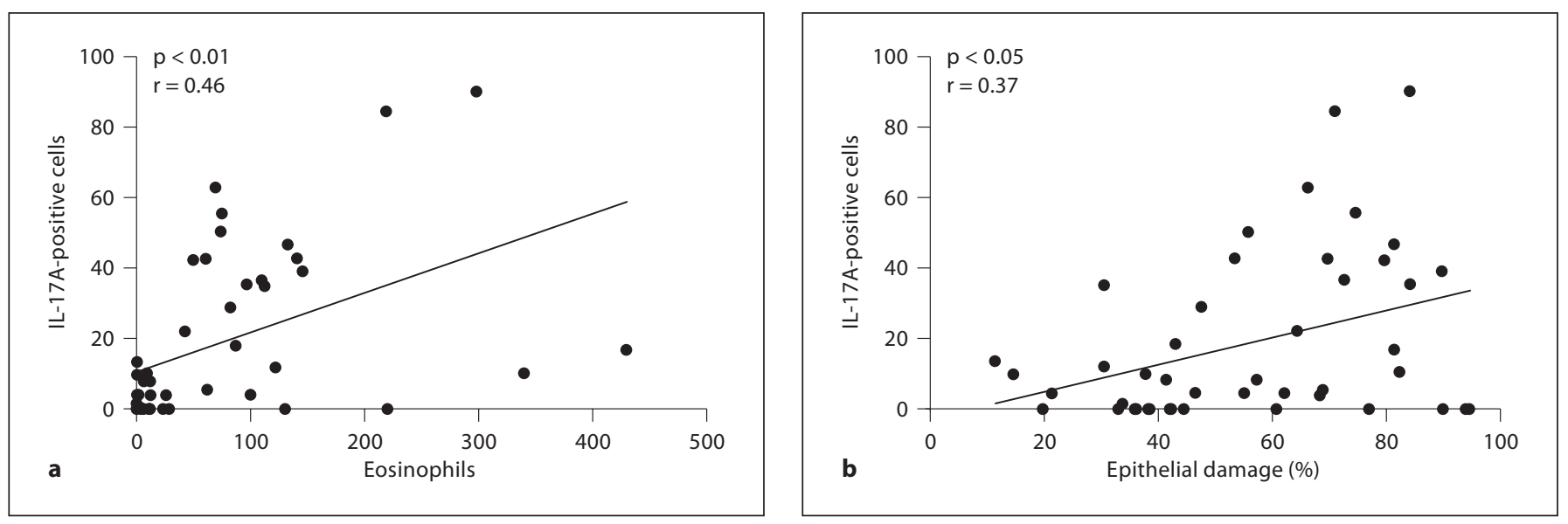

Fig. 5. Relevance of the number of the IL-17A-positive cells to the number of the eosinophils (a), epithelial damage (b) and BM thickness (c).
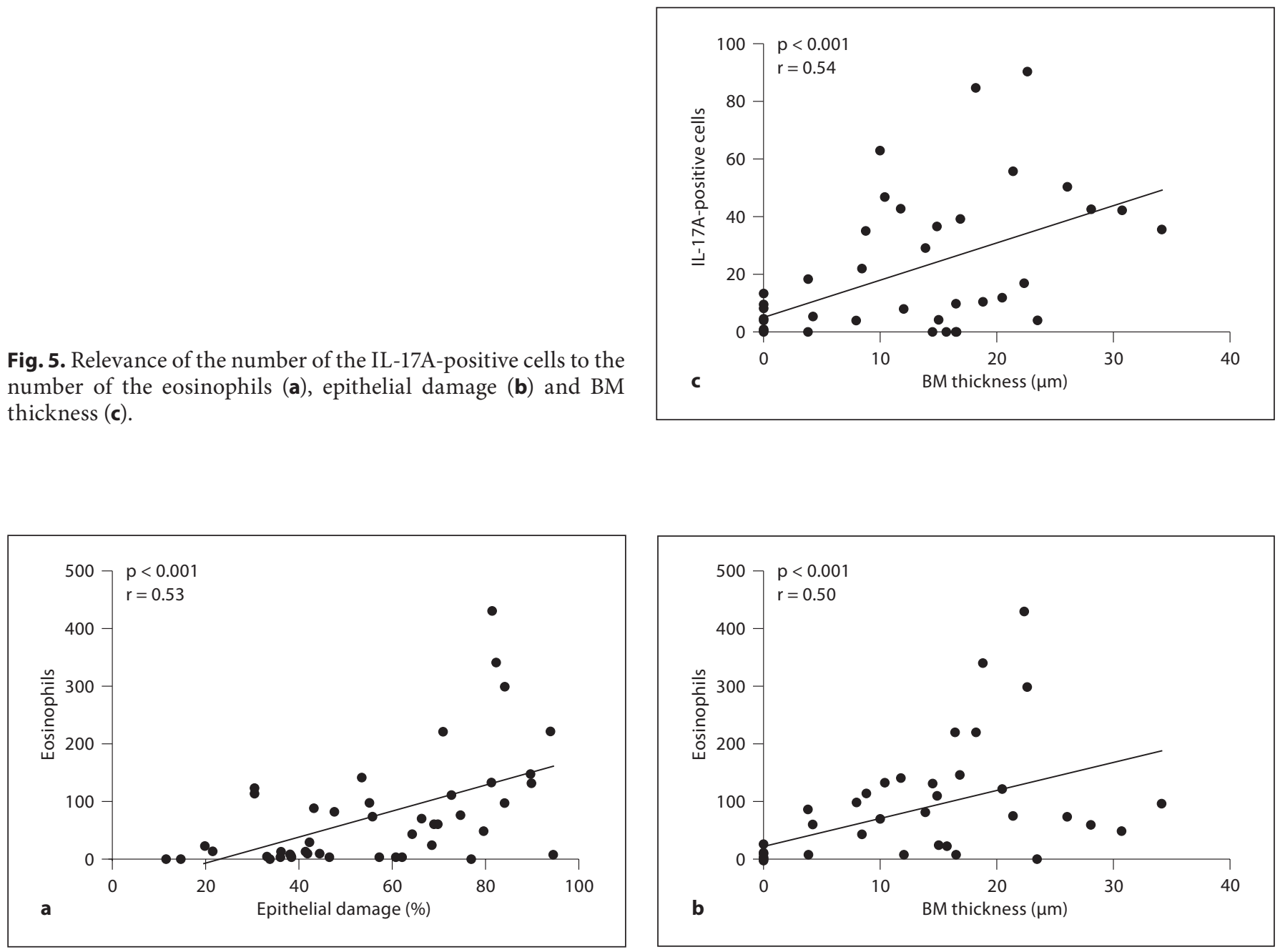

Fig. 6. Relevance of eosinophilic infiltration to epithelial damage (a) and BM thickness (b). 
icant expression of IL-17A at both the protein and mRNA levels in the nasal polyps of CRS associated with asthma in comparison with the normal sinus mucosa, which confirms that IL-17A contributes to the underlying pathology of nasal polyps.

T lymphocytes of the CD4- and CD8-positive subsets produce and release IL-17A upon activation [42]. Granulocytes may be alternative sources of IL-17A $[27,43]$. The immunoreactivity and mRNA for intracellular IL-17A are detected in eosinophils harvested from the bronchoalveolar fluid, induced sputum and peripheral blood of patients with asthma [27]. In addition, the presence of IL-17A mRNA was observed in the bronchoalveolar neutrophils stimulated by endotoxin [43]. In the upper airway, the cellular sources for IL-17A are reported to be T lymphocytes, neutrophils, eosinophils, plasma cells and serous glands $[34,35]$. The present study clearly showed that IL-17A was predominantly expressed in both CD4-positive lymphocytes and eosinophils, but not in neutrophils.

In addition to the Th1/Th2 paradigm, a third T-cell subset, known as Th17 cells, was identified and characterized by the production of IL-17A [44, 45]. Th17 cells play an important role in the pathogenesis of a diverse group of immune-mediated diseases including asthma and other allergic diseases $[46,47]$. The increased expression of IL-17A in the lung during asthma is proposed to induce the increased accumulation and activation of lung neutrophils via the upregulation of chemoattractants for neutrophils and neutrophil-activating cytokines [27, 32, 48, 49]. On the other hand, nasal polyps are characterized by a considerable number of IL-17A-positive cells which are strongly correlated with the number of eosinophils. The correlation between IL-17A-positive cells and eosinophils can be simply explained by the fact that the major source of IL-17A is eosinophils. The more important finding is that the cells positive for both CD4 and IL-17A are significantly correlated with eosinophil accumulation into the sinonasal mucosa, suggesting that chemokines and/or adhesion molecules for eosinophils are upregulated by CD4-positive T cells expressing IL-17A. A previous study indicated that the eotaxin family production enhanced by eosinophils results in the recruitment of eosinophils into nasal polyp and sinus effusion by a self-amplifying process and then contributes to the exacerbation of the sinonasal inflammation [50]. Eotaxin is reported to be produced by human airway smooth muscle cells cultured with IL-17A [51]. Taken together, these data suggest that IL-17A primarily attributed to Th17 cells induces the recruitment of eosinophils, which is enhanced by a positive feedback loop of IL-17A production by eosinophils. Fur- ther studies are required to clarify the underlying mechanism of eosinophil recruitment in relation to IL-17A.

The present study focusing on the nasal polyps of CRS associated with asthma is likely to show a manner of the recruitment of granulocytes different from asthma in relation to IL-17A. IL-17A has been believed to induce neutrophilic airway inflammation in patients with asthma [23-26] and a mouse model of asthma [52]. However, recent studies using a murine asthma model have shown that IL-17A induces recruitment not only of neutrophils but also of eosinophils into the airways [53, 54]. The role of IL-17A presented in nasal polyps of CRS might be explained by upregulation of Th2 cell-mediated eosinophilic airway inflammation as indicated in the mouse model of asthma [55]. The distinct roles of IL-17A between upper and lower airway inflammation may be related to frequent exposure to microbial and viral agents in the upper airway, which are known to trigger a strong IL-17 response [56]. Although the mechanism underlying Th17A cell-mediated enhancement of Th2 cell-mediated eosinophil recruitment into the airway is unknown, our findings may contribute to a better understanding of the pathogenesis of CRS with nasal polyps.

The present study found that the infiltration of IL17A-positive cells had a significant correlation with the epithelial damage and BM thickness. Chakir et al. [52] suggested that the important features of airway remodeling in asthma include the formation of subepithelial fibrosis and increased deposition of types I and III collagen. Transforming growth factor- $\beta$, IL-11 and IL-17A are profibrotic cytokines involved in the formation of subepithelial fibrosis and are increased in patients with asthma, which is consistent with the current results. However, no association of IL-17A with epithelial damage of the airway has been elucidated until the present study. There is a close relationship between mucosal remodeling of nasal polyps and eosinophilic infiltration [53], which is consistent with the present findings (fig. 6). Therefore, mucosal remodeling of nasal polyps is thought to be related to cytotoxic mediators derived from eosinophils and/or the profibrotic capability of IL-17A.

In conclusion, the present study suggests that IL-17A plays an important role in both the eosinophil infiltration and the remodeling of the nasal polyps of CRS associated with asthma.

\section{Acknowledgments}

We thank Noriko Shindo, Takako Shigihara and Tomomi Ikeda for their excellent technical assistance. 


\section{References}

- Benninger MS, Ferguson BJ, Hadley JA, Hamilos DL, Jacobs M, Kennedy DW, Lanza DC, Marple BF, Osguthorpe JD, Stankiewicz JA, Anon J, Denneny J, Emanuel I, Levine H: Adult chronic rhinosinusitis: definitions, diagnosis, epidemiology, and pathophysiology. Otolaryngol Head Neck Surg 2003;129: S1-S32.

2 Kaliner MA, Osguthorpe JD, Fireman P, Anon J, Georgitis J, Davis ML, Naclerio R, Kennedy D: Sinusitis: bench to bedside. Current findings, future directions. J Allergy Clin Immunol 1997;99:S829-S848.

-3 Meltzer EO, Hamilos DL, Hadley JA, Lanza DC, Marple BF, Nicklas RA, Bachert C, Baraniuk J, Baroody FM, Benninger MS, Brook I, Chowdhury BA, Druce HM, Durham S, Ferguson B, Gwaltney JM, Kaliner M, Kennedy DW, Lund V, Naclerio R, Pawankar R, Piccirillo JF, Rohane P, Simon R, Slavin RG, Togias A, Wald ER, Zinreich SJ: Rhinosinusitis: establishing definitions for clinical research and patient care. J Allergy Clin Immunol 2004;114:S155-S212.

4 Fokkens W, Lund V, Mullol J: European position paper on rhinosinusitis and nasal polyps. Rhinology 2007;45(suppl 20):1-139.

5 Polzehl D, Moeller P, Riechelmann H, Perner S: Distinct features of chronic rhinosinusitis with and without nasal polyps. Allergy 2006; 61:1275-1279.

-6 van Zele T, Claeys S, Genaert P, van Maele G, Holtappels G, van Cauwenberge P, Bachert C: Differentiation of chronic sinus disease by measurement of inflammatory mediators. Allergy 2006;61:1280-1289.

7 Eichel BS: A proposal for a staging system for hyperplastic rhinosinusitis based on the presence or absence of intranasal polyposis. Ear Nose Throat J 1999;78:262-265.

8 Georgitis JW, Matthews BL, Stone B: Chronic sinusitis: characterization of cellular influx and inflammatory mediators in sinus lavage fluid. Int Arch Allergy Immunol 1995; 196:416-421.

-9 Suzuki H, Wataya H, Takahashi Y, Ikeda K, Shimomura A, Nakabayashi S, Takasaka T: Mechanism of neutrophil recruitment induced by interleukin- 8 in chronic sinusitis. J Allergy Clin Immunol 1996;98:659-670.

10 Suzuki H, Shimomura A, Ikeda K, Oshima T, Takasaka T: Effects of long-term low-dose macrolide administration on neutrophil recruitment and IL- 8 in the nasal discharge of chronic sinusitis patients. Tohoku J Exp Med 1997;182:115-124.

11 Suzuki H, Ikeda K: Mode of action of longterm low-dose macrolide therapy for chronic sinusitis in the light of neutrophil recruitment. Curr Drug Targ Inflamm Allergy 2000;1:117-126.
12 Hamilos D, Leung DYM, Wood R, Meyers A, Stephens JK, Barkans J, Meng Q, Cunningham L, Bean DK, Kay AB, et al: Chronic hyperplastic sinusitis: association of tissue eosinophilia with mRNA expression of granulocyte-macrophage colony-stimulating factor and interleukin-3. J Allergy Clin Immunol 1993;92:39-48.

13 Dinis PB, Gomes A: Sinusitis and asthma: how do they interrelate in sinus surgery? Am J Rhinol 1997;11:421-428.

14 Dejima K, Hama T, Miyazaki M, Yasuda S, Fukushima K, Oshima A, Yasuda M, Hisa Y: A clinical study of endoscopic sinus surgery for sinusitis in patients with bronchial asthma. Int Arch Allergy Immunol 2005; 138:97104.

15 Hamilos D: Chronic sinusitis. J Allergy Clin Immunol 2000;106:213-227.

16 Steinke JW: The relationship between rhinosinusitis and asthma sinusitis. Curr Allergy Asthma Rep 2006;6:495-501.

17 Slavin RG: Asthma and sinusitis. J Allergy Clin Immunol 1992;90:534-537.

$\checkmark 18$ Bachert C, Gevaaert P, Holtappels G, Cuvelier C, Van Cauwenberge P: Nasal polyposis: from cytokines expressions to growth. Am J Rhinol 2000;14:279-290.

19 Elhini A, Abdelwahab S, Ikeda K: Th1 and Th2 cell population in chronic ethmoidal rhinosinusitis: a chemokine receptor assay. Laryngoscope 2005;115:1272-1277.

20 Naylor B: The shedding of the mucosa of the bronchial tree in asthma. Thorax 1962;17: 69-72.

-21 Roche WR, Beasley R, Williams JH, Holgate ST: Subepithelial fibrosis in the bronchi of asthmatics. Lancet 1989;i:520-524.

22 Ponikau JU, Sherris DA, Kephart GM, Kern EB, Gaffey TA, Tarara JE, Kita H: Features of airway remodeling and eosinophilic inflammation in chronic rhinosinusitis: is the histopathology similar to asthma? J Allergy Clin Immunol 2003;112:877-882.

23 Wenzel SE, Schwartz LB, Langmack EL, Halliday JL, Trudeau JB, Gibbs RL, Chu HW: Evidence that severe asthma can be divided pathologically into two inflammatory subtypes with distinct physiologic and clinical characteristics. Am J Respir Crit Care Med 1999;160:1001-1008.

24 Amin K, Lúdvíksdóttir D, Janson C, Nettelbladt O, Björnsson E, Roomans GM, Boman G, Sevéus L, Venge P: Inflammation and structural changes in the airways of patients with atopic and nonatopic asthma. BHR Group. Am J Respir Crit Care Med 2000;162: 2295-2301.

25 Gibson PG, Simpson JL, Saltos N: Heterogeneity of airway inflammation in persistent asthma: evidence of neutrophilic inflammation and increased sputum interleukin-8. Chest 2001;119:1329-1336.
26 Douwes J, Gibson P, Pekkanen J, Pearce N: Non-eosinophilic asthma: importance and possible mechanisms. Thorax 2002;57:643648 .

27 Molet S, Hamid Q, Davoine F, Nutku E, Taha R, Pagé N, Olivenstein R, Elias J, Chakir J: IL-17 is increased in asthmatic airways and induces human bronchial fibroblasts to produce cytokines. J Allergy Clin Immunol 2001;108:430-438.

28 Wong CK, Ho CY, Ko FW, Chan CH, Ho AS, Hui DS, Lam CW: Proinflammatory cytokines (IL-17, IL-6, IL-18 and IL-12) and Th cytokines (IFN-gamma, IL-4, IL-10 and IL13) in patients with allergic asthma. Clin Exp Immunol 2001;125:177-183.

29 Barczyk A, Pierzchala W, Sozañska E: Interleukin-17 in sputum correlates with airway hyperresponsiveness to methacholine. Respir Med 2003;97:726-733.

30 Bullens DM, Truyen E, Coteur L, Dilissen E, Hellings PW, Dupont LJ, Ceuppens JL: IL-17 mRNA in sputum of asthmatic patients: linking $\mathrm{T}$ cell driven inflammation and granulocytic influx? Respir Res 2006;7:135.

31 Vanaudenaerde BM, Wuyts WA, Dupont LJ, Van Raemdonck DE, Demedts MM, Verleden GM: Interleukin-17 stimulates release of interleukin- 8 by human airway smooth muscle cells in vitro: a potential role for interleukin17 and airway smooth muscle cells in bronchiolitis obliterans syndrome. J Heart Lung Transplant 2003;22:1280-1283.

- 32 Henness S, Johnson CK, Ge Q, Armour CL, Hughes JM, Ammit AJ: IL-17A augments TNF-alpha-induced IL-6 expression in airway smooth muscle by enhancing mRNA stability. J Allergy Clin Immunol 2004;114: 958-964.

33 Van Bruaene N, Pérez-Novo CA, Basinski TM, Van Zele T, Holtappels G, De Ruyck N, Schmidt-Weber C, Akdis C, Van Cauwenberge P, Bachert C, Gevaert P: T-cell regulation in chronic paranasal sinus disease. J Allergy Clin Immunol 2008;121:1435-1441, 1441.e1-e3.

34 Wang X, Dong Z, Zhu DD, Guan B: Expression profile of immune-associated genes in nasal polyps. Ann Otol Rhinol Laryngol 2006;115:450-456

35 Molet SM, Hamid QA, Hamilos DL: IL-11 and IL-17 expression in nasal polyps: relationship to collagen deposition and suppression by intranasal fluticasone propionate. Laryngoscope 2003;113:1803-1812.

36 Fokkens W, Lund V, Bachert C, Clement P, Helllings $\mathrm{P}$, Holmstrom $\mathrm{M}$, Jones $\mathrm{N}$, Kalogjera L, Kennedy D, Kowalski M, Malmberg H, Mullol J, Passali D, Stammberger H, Stierna P: EAACI position paper on rhinosinusitis and nasal polyps executive summary. Allergy 2005;260:583-601. 
-37 Ikeda K, Kondo Y, Sunose H, Hirano K, Oshima T, Shimomura A, Suzuki H, Takasaka T: Subjective and objective evaluation in endoscopic sinus surgery. Am J Rhinol 1996; 10:217-220.

>38 Lund VJ, Mackay IS: Staging in rhinosinusitis. Rhinology 1993;31:183-184.

-39 Barbato A, Turato G, Baraldo S, Bazzan E, Calabrese F, Panizzolo C, Zanin ME, Zuin R, Maestrelli P, Fabbri LM, Saetta M: Epithelial damage and angiogenesis in the airways of children with asthma. Am J Respir Crit Care Med 2006;174:975-981.

-40 Hamilos DL, Leung DY, Wood R, Cunningham L, Bean DK, Yasruel Z, Schotman E, Hamid Q: Evidence for distinct cytokine expression in allergic versus nonallergic chronic sinusitis. J Allergy Clin Immunol 1995;96: 537-544.

-41 Van Bruaene N, Pérez-Novo CA, Basinski TM, Van Zele T, Holtappels G, De Ruyck N, Schmidt-Weber C, Akdis C, Van Cauwenberge P, Bachert C, Gevaert P: T-cell regulation in chronic paranasal sinus disease. J Allergy Clin Immunol 2008;121:1435-1441, 1441.e1-e3.

$\checkmark 42$ Yao Z, Painter SL, Fanslow WC, Ulrich D, Macduff BM, Spriggs MK, Armitage RJ: Human IL-17: a novel cytokine derived from T cells. J Immunol 1995; 155:5483-5486.

-43 Ferretti S, Bonneau O, Dubois GR, Jones CE, Trifilieff A: IL-17, produced by lymphocytes and neutrophils, is necessary for lipopolysaccharide-induced airway neutrophilia: IL15 as a possible trigger. J Immunol 2003;170: 2106-2112.
44 Harrington LE, Hatton RD, Mangan PR, Turner H, Murphy TL, Murphy KM, Weaver CT: Interleukin 17-producing CD4+ effector T cells develop via a lineage distinct from the Thelper type 1 and 2 lineages. Nat Immunol 2005;6:1123-1132.

45 Park H, Li Z, Yang XO, Chang SH, Nurieva R, Wang YH, Wang Y, Hood L, Zhu Z, Tian Q, Dong C: A distinct lineage of CD4 T cells regulates tissue inflammation by producing interleukin 17. Nat Immunol 2005;6:11331141.

46 Tesmer LA, Lundy SK, Sarkar S, Fox DA: Th17 cells in human disease. Immunol Rev 2008;223:87-113.

47 Oboki K, Ohno T, Saito H, Nakae S: Th17 and allergy. Allergol Int 2008;57:121-134.

48 Lindén A: Role of interleukin-17 and the neutrophil in asthma. Int Arch Allergy Immunol 2001;126:179-184

49 Dragon S, Rahman MS, Yang J, Unruh H, Halayko AJ, Gounni AS: IL-17 enhances IL1beta-mediated CXCL- 8 release from human airway smooth muscle cells. Am J Physiol Lung Cell Mol Physiol 2007;292: L1023-L1029.

50 Yao T, Kojima Y, Koyanagi A, Yokoi H, Saito T, Kawano K, Furukawa M, Kusunoki T, Ikeda K: Eotaxin-1, -2, and -3 immunoreactivity and protein concentration in the nasal polyps of eosinophilic chronic rhinosinusitis patients. Laryngoscope, in press.

51 Rahman MS, Yamasaki A, Yang J, Shan L, Halayko AJ, Gounni AS: IL-17A induces eotaxin-1/CC chemokine ligand 11 expression in human airway smooth muscle cells: role of MAPK (Erk1/2, JNK, and p38) pathways. J Immunol 2006;177:4064-4071.
2 Hellings PW, Kasran A, Liu Z, Vandekerckhove P, Wuyts A, Overbergh L, Mathieu C, Ceuppens JL: Interleukin-17 orchestrates the granulocyte influx into airways after allergen inhalation in a mouse model of allergic asthma. Am J Respir Cell Mol Biol 2003;28: 42-50.

53 Schnyder-Candrian S, Togbe D, Couillin I, Mercier I, Brombacher F, Quesniaux V, Fossiez F, Ryffel B, Schnyder B: Interleukin17 is a negative regulator of established allergic asthma. J Exp Med 2006;203:27152725

54 Wakashin H, Hirose K, Maezawa Y, Kagami S, Suto A, Watanabe N, Saito Y, Hatano M, Tokuhisa T, Iwakura Y, Puccetti P, Iwamoto I, Nakajima H: IL-23 and Th17 cells enhance Th2-cell-mediated eosinophilic airway inflammation in mice. Am J Respir Crit Care Med 2008;178:1023-1032.

55 Korn T, Bettelli E, Oukka M, Kuchroo VK: IL-17 and Th17 cells. Annu Rev Immunol 2009;27:485-517.

56 Chakir J, Shannon J, Molet S, Fukakusa M, Elias J, Laviolette M, Boulet LP, Hamid Q: Airway remodeling-associated mediators in moderate to severe asthma: effect of steroids on TGF-beta, IL-11, IL-17, and type I and type III collagen expression. J Allergy Clin Immunol 2003;111:1293-1298.

57 Saitoh T, Kusunoki T, Yao T, Kawano K, Kojima Y, Miyahara K, Onoda J, Yokoi H, Ikeda $\mathrm{K}$ : Relevance of epithelial damage and basement membrane thickness to eosinophilic infiltration in nasal polyps of chronic rhinosinusitis; submitted. 